Original article

\title{
High energy and carbohydrate consumption among Mayan community women with type 2 diabetes.
}

\author{
Karen Castillo-Hernández ${ }^{1 *}$, Alan Espinosa-Marrón ${ }^{1}$, Fernanda Molina-Segui ${ }^{1}$, Rossana Caracashian- \\ Díaz ${ }^{1}$, Hugo Laviada-Molina ${ }^{1}$. \\ 1 Department of Metabolism and Human Nutrition Research, Universidad Marista de Mérida, Merida Yucatan \\ 97300, Mexico. \\ * Correspondence: nutricalli@gmail.com; Tel.: +52 (999) 1114559.
}

\begin{abstract}
:
Aim: To perform a descriptive analysis of eating patterns and biophysical conditions of previously diagnosed and currently under treatment individuals from a semi-urban Mayan community of Yucatan, and to contrast them with T2DM therapeutic guidelines.

Methods: The present study is derived from a randomized clinical trial conducted at Komchen, Yucatan. Participants' diagnosed with T2DM were included. A 24-hour dietary recall, anthropometric parameters (weight, visceral fat, height, and waist circumference), biochemical (HbA1c) and clinical (blood pressure) variables were evaluated and compared via hypothesis test with T2DM treatment cut-off points (based on World Health Organization criteria).

Results: Anthropometric characteristics differ significantly from the ideal criteria. Obesity prevalence within women with T2DM was $92.9 \%$. Only $21 \%$ of the participants were under T2DM control $(\leq 7 \%)$. Energy and carbohydrates consumption, significantly exceed therapeutic guidelines, whereas protein, fat, and fiber intake were lower than the recommendations.

Conclusions: Komchen's diet, concomitantly with food characteristics, could be related to glycemic decontrol. There is a disproportion in macronutrients consumption in favor of carbohydrates, probably associated with socioeconomic limitations, food availability, and price. Developing nutritional assistance programs which contemplate cultural and economic factors in this Mayan population must be taken into consideration.
\end{abstract}

Keywords: Diet composition; Food culture; Mayan community; Type 2 diabetes mellitus.

\section{Introduction}

With globalization, the Mexican diet has substituted traditional local products (with a predominance of plant-based foods) for an industrialized higher-energy-density diet characterized by processed products $[1,2]$.

Yucatan, located in the southeast of Mexico, is the 5th entity with the highest proportion of indigenous population in the country [3] and it has also experienced demographic and epidemiological changes influenced by decades of industrialization, which has modified food consumption patterns and nutritional status. It is well known that the most affected communities in Yucatan have been indigenous groups with Mayan ancestry [1,4]. A clear example is the increase in sugar consumption through bottled beverages reported in this population [5]. Labor activities such as agriculture in this region have migrated to sedentary activities, such as work in the industrial, commercial and service sectors [6]. A sedentary lifestyle 
contributes synergistically to develop chronic non-communicable diseases. This phenomenon has increased obesity and Type 2 diabetes mellitus (T2DM) prevalence in Yucatan [7].

Furthermore, Yucatecan communities suffer a high rate of marginalization. More than $50 \%$ of its inhabitants earn less than $16 \mathrm{USD} /$ day and between 40 and $80 \%$ of its population did not complete elementary education [8]. The high poverty rate among indigenous communities limits access to health services and food quality, which can increase high-caloric food consumption and exacerbate T2DM complications [9].

Previous studies had described food patterns within Mayan communities in the Yucatan peninsula, however current dietary habits regarding people with T2DM in these groups and how their diet fits into the standards of care for T2DM management and control had not been reported. Therefore, the objective of this study is to perform a descriptive analysis regarding eating patterns and biophysical conditions of previously diagnosed and currently under treatment individuals from a semi-urban Mayan community of Yucatan, and contrast them with Mexican therapeutic guidelines which are based on World Health Organization (WHO) criteria.

\section{Materials and Methods}

The present study is derived from a randomized clinical trial (RCT) conducted in Komchen, Yucatan, from March to November 2015 (registration number in ISRCTN 40146390). This community is located 19 $\mathrm{km}$ north from the City of Merida, capital of Yucatan State. The population is 4,259 inhabitants, with indigenous Mayan ancestry as their greatest majority [10]. RCT participants' records were identified, those with a previous diagnosis of T2DM were included, and those who also had a 24-hour dietary recall (R-24), biochemical and clinical data before the RCT intervention. Of 64 cases identified, 59 met the inclusion criteria, 57 of them were from women. Considering that an accurate analysis implicates gender segmentation, files belonging to male volunteers were excluded, due to lack of representativeness. All volunteers had a previous diagnosis of T2DM ( $9 \pm 7$ years) and are also treated in local public clinics where they receive medical and basic nutritional advice.

\subsection{Anthropometric variables}

Body weight measurement $(\mathrm{kg})$

An octopolar body composition analyzer OMRON®, model BF511, was used. To estimate body weight, indications established in the OMRON® model manual were followed.

\section{$\underline{\text { Height measurement }(\mathrm{cm})}$}

A SECA ${ }^{\circledR}$ portable stadiometer was used. Participants stood up without shoes or ornaments on their heads that could bias the measurement. Participants stood firm, so that heels were attached to the longitudinal axes of both feet and that they kept a $45^{\circ}$ between them. Arms hung free and naturally along the body, head was maintained in a Frankfort horizontal plane. A stature $<150 \mathrm{~cm}$ was considered as short stature [11].

\section{Body Mass Index Calculation (BMI)}

Quetelet formula $\left(\mathrm{BMI}=\right.$ weight $[\mathrm{kg}] /$ height $\left.[\mathrm{m}]^{2}\right)$ was performed for BMI calculation, considering variables of weight and height previously described. Cut-off points for BMI classification were those established in NOM-008-SSA3-2017. For short stature adults ( $<150 \mathrm{~cm}$ in women, $<163 \mathrm{~cm}$ in men), a BMI 
$<22.9 \mathrm{~kg} / \mathrm{m} 2$ was considered as normal. On the other hand, for third-age adults ( $\geq 60$ years), $<27.9 \mathrm{~kg} / \mathrm{m} 2$ was taken as ideal criteria. For third-age adults who also presented short stature, $<24.9 \mathrm{~kg} / \mathrm{m} 2$ was considered as recommended parameter [11]. For ideal body weight (IBW) calculation, the following formula was applied: $\boldsymbol{I} \boldsymbol{B} \boldsymbol{W}=\boldsymbol{I} \boldsymbol{B} \boldsymbol{M I}\left(\frac{\boldsymbol{k g}}{\boldsymbol{m}^{2}}\right) \times \boldsymbol{H}^{2}(\boldsymbol{m})$; where: IBW= ideal body weight, IBMI= ideal body mass index (considering individual cut-off points), $\mathrm{H}=$ height.

\section{Waist circumference (W.C) measurement}

A SECA ${ }^{\circledR}$ metric tape was used for measurement, which was placed at the midpoint between the last rib and the most superior and lateral point of the iliac crest, while subject held relaxed arms hanging on each side. Result was taken at the end of a normal expiration. A value $<80 \mathrm{~cm}$ was considered as ideal parameter [12].

\section{Estimation of visceral fat}

Estimation was performed through the OMRON® (BF511) body composition analyzer, which bases its calculation on bioelectrical impedance, and classifies area of visceral adiposity in levels as following: 1-9= normal, $10-11=$ high, $15-30$ = very high. A level $\leq 9$ was considered as ideal criteria.

\section{Blood pressure determination $(\mathrm{mmHg})$}

An electronic blood pressure monitor was used (OMRON® model BF 500). Measurement was performed in duplicate, average between both measurements was taken following the technique described in equipment's manual and in Guidelines on the management of arterial hypertension and related comorbidities in Latin America [13]. An ideal parameter for systolic and diastolic pressure was $<130 /<80$ $\mathrm{mmHg}$, respectively, in agreement with the NOM-015-SSA2-2010 for blood pressure control in people with T2DM [14].

\subsection{Biochemical variables}

\section{Determination of glycated hemoglobin (HbA1c)}

A venous blood sample was taken by trained personnel, who stored samples in BD Vacutainer ${ }^{\circledR}$ tubes with EDTA-K2 for further analysis (fasting conditions were not required). A high-pressure liquid chromatography method was followed in agreement with The National Glycohemoglobin Standardization Program recommendations. A percentage $\leq 7$ of HbA1c was considered as ideal criteria, as stipulated by Mexican guideline NOM-015-SSA2-2010, for prevention, treatment, and control of T2DM [14].

\subsection{Dietetic variables}

To identify the approximate energy and nutrients consumption in this Mayan individuals' sample, a R-24 was applied in a previously validated format. The application was performed by nutritionists previously trained and standardized for its application.

\section{Nutritional calculation}

Food intake information was collected through the R-24. Conversions were made to obtain food serving portions according to the Mexican System of Equivalent Foods [15]. Energy and nutrients intake 
were analyzed. Each individual total carbohydrate, fiber, protein, lipid, and kilocalories (kcal) consumption from the day before survey were estimated.

\section{Estimation of ideal values}

Recommended daily energy intake (kcal) was obtained through multiplying each volunteer ideal body weight $(\mathrm{kg})$ by $25 \mathrm{kcal}$, as a constant for a female overweight/obese population with T2DM, as stipulated in NOM-015-SSA2-2010 for T2DM control [14]. Regarding nutrients total energetic value (TEV), 52 $\pm 2.5,17 \pm$ 2.5 , and $27 \pm 2.5$ was considered as ideal percentages for carbohydrates, proteins and lipids, respectively $[14,16]$. An intake $<200 \mathrm{mg} /$ day of total cholesterol was taken as adequate, as recommended in the Mexican guidelines for people with T2DM [14]. Finally, an intake of $14 \mathrm{gr}$ of fiber per 1,000 kcal was established as ideal [14].

\subsection{Ethical considerations}

This study was approved by Ethics Committee from the Medicine Faculty from "Universidad Autónoma de Yucatán", Mexico, dated November 21, 2014 (21-11-2014-FMed-UADY) in accordance with regulations about research protocols by Secretary of Health of Mexico (NOM-012-SSA3-2012) and Declaration of Helsinki of 1975. Informed consent was read and explained to every study candidate, who subsequently signed that they agreed to participate.

\subsection{Statistical Analysis}

A Shapiro-Wilk normality test was performed for continuous variables. A Student's t-test and hypothesis test were applied for means comparison. The association between dietary intake and HbA1c was assessed with a Pearson's correlation coefficient. A p $\leq 0.05$ was considered to indicate a significant difference. Data were processed with Statgraphics version V.I.

\section{Results}

Results are derived from the RCT's participants in baselines conditions. This study describes the eating behaviors and biophysical conditions of a suburban Mayan indigenous community from Yucatan, Mexico. We included and analyzed data from 57 women ( $57.4 \pm 9.8$ years) most of them with short stature (1.46 \pm $0.05 \mathrm{~m}$ ), with a previous diagnosis of T2DM. Regarding biochemical and anthropometric parameters, a significant difference in HbA1c, weight, visceral fat level, and W.C. was identified when comparing Komchen's population with ideal criteria (Table 1). According to BMI individual diagnosis $(30.0 \pm 4.7$ $\left.\mathrm{kg} / \mathrm{m}^{2}\right), 92.9 \%$ of the participants presented overweight/obesity. Furthermore, only $21 \%$ of participants are in $\mathrm{T} 2 \mathrm{DM}$ control (HbA1c $\leq 7 \%)$.

The most frequently consumed products were identified via the R-24 food questionnaire tool, data from day before survey was collected (table 2). Corn tortilla was the most consumed grain-based product, especially at lunchtime, and it constitutes feeding basis in the community. In addition to tortillas, other high-carbohydrate foods intake was observed: low-fat cookies (crackers), french bread (a traditional baguette consumed in this area), sweet bread, sugar-sweetened beverages, white bread, and oatmeal (in this order). Less consumed but also contributing to total carbohydrate and energy intake are rice, pasta, and wholemeal bread and boxed breakfast cereal. Of the eleven grain-based product consumed among participants, five are considered ultra-processed [2]. 
Regarding fruits; mango, banana, and orange are those that are consumed more frequently, mainly as a snack. The most consumed vegetables are squash, chayote, tomato, and carrot. However, we identified a very low consumption of fruits and vegetables among this community (1.8 serving portions/person/day). For legumes, only beans and lentils are consumed. Beans are more frequently consumed, mainly at lunchtime.

Concerning animal-derived products (ADP); pork, egg, and chicken, are consumed most often. It should be noted that high-fat cheese is another ADP with high consumption (27 serving portions), in contrast, only two portions of low-fat cheese were consumed by the sample group. Oil was included as an ingredient for food preparation, being the fat-based food that was consumed in larger proportions. It should be noticed that walnuts were not consumed.

Added sugar intake was analyzed. We consider added sugar as the amount of sugar intentionally added to food, together with the quantity contained in products such as sweet bread (60 gr as serving portion) and sweetened beverages (92 gr as serving portion), in agreement with the United States Department of Agriculture Branded Food Products Database [18] and Mexican System of Equivalent Foods [16], respectively. Of 52 volunteers, 35 of them reported consuming added sugar. Furthermore, bottled beverages (mainly sugary carbonated beverages) were consumed during the entire day, higher consumption was observed at lunchtime. Nutritional analysis derived from the R-24 is presented in table 3.

When comparing participants' diet characteristics with the ideal dietary criteria for T2DM treatment (Table 4), we found that caloric intake, as well as carbohydrates TEV (\%) exceeds recommended parameters significantly. In this matter, we found a positive association between carbohydrate intake $(223.3 \pm 74.7$, in grams) and increased HbA1c levels in obese participants ( $r=0.4509, p=0.0237)$. Conversely, a lower consumption of protein, lipids and fiber were found in comparison with ideal intake. 
Table 1. Comparison between clinical characteristics among Mayan community women with type 2 diabetes vs ideal criteria.

\begin{tabular}{|c|c|c|c|}
\hline Variables & $\begin{array}{c}\text { Participants } \\
n=57 \\
\text { Mean } \pm \text { SD }\end{array}$ & Ideal criteria & $p$ value \\
\hline Weight (kg) & $63.7 \pm 11.8$ & $50.8 \pm 4.4^{a}$ & $<0.0001$ \\
\hline W.C. $(\mathrm{cm})$ & $95.6 \pm 9.7$ & $\leq 80^{\mathrm{b}}$ & $<0.0001$ \\
\hline Visceral fat (level) & $10.5 \pm 2.2$ & $\leq 9^{c}$ & $<0.0001$ \\
\hline $\mathrm{SP}(\mathrm{mmHg})$ & $128.5 \pm 25.0$ & $<130^{d}$ & 0.7908 \\
\hline $\mathrm{DP}(\mathrm{mmHg})$ & $78.4 \pm 12.0$ & $<80^{\mathrm{d}}$ & 0.8285 \\
\hline HbA1c (\%) & $8.7 \pm 2.0$ & $\leq 7 \mathrm{~d}$ & $<0.0001$ \\
\hline
\end{tabular}

Note: means comparison performed by a paired Student $t$-test. Mean comparison vs pre-established population cut-off points performed by hypothesis test.

Abbreviations: $\mathrm{BMI}=$ body mass index; $\mathrm{HbA1c}=$ glycated hemoglobin; W.C $=$ waist circumference; $\mathrm{SP}=$ systolic pressure; $\mathrm{DP}=$ diastolic pressure.

a IBW $(\mathrm{kg})=\operatorname{IMBI}\left(\frac{\mathrm{kg}^{2}}{\mathrm{~m}}\right) \times \mathrm{H}(\mathrm{m})^{2}$; where: IBW=ideal body weight, IBMI= ideal body mass index (considering individual cut-off points), $\mathrm{H}=$ height.

${ }^{b}$ Ideal criteria: World Health Organization cut off point for female.

c Ideal criteria: maximum normal level recommended by the OMRON® impedance device used.

d Ideal criteria: treatment goal according to NOM-015-SSA2-2010 for A1c and blood pressure control in people with T2DM. 
Table 2. Accumulated serving portions consumed by sampled group $(n=57)$ from a Mayan community in daily basis.

\begin{tabular}{|c|c|c|c|c|c|}
\hline Food & Breakfast & Meal & Dinner & Snacks & Total \\
\hline \multicolumn{6}{|l|}{ Grain-derived products } \\
\hline Corn tortilla & 46 & 229 & 43.5 & 0 & 318.5 \\
\hline Low-fat cookies & 15 & 0 & 30 & 3 & 48 \\
\hline French bread & 20 & 1 & 16.5 & 0 & 37.5 \\
\hline Sweetbread & 13 & 1 & 7 & 5.5 & 26.5 \\
\hline White bread & 12 & 0 & 8 & 1 & 21 \\
\hline Oatmeal & 13 & 0 & 6 & 1 & 20 \\
\hline Cookies & 9 & 1.5 & 2 & 5 & 17.5 \\
\hline Rice & 0.5 & 9 & 1 & 0 & 10.5 \\
\hline Pasta & 0 & 3.5 & 5 & 0 & 8.5 \\
\hline Wholemeal bread & 4 & 2 & 0 & 0 & 6 \\
\hline Cash cereal & 0 & 0 & 1 & 4 & 5 \\
\hline \multicolumn{6}{|l|}{ Fruits } \\
\hline Mango & 0 & 0 & 2 & 11 & 13 \\
\hline Banana & 2 & 0.5 & 0 & 8.5 & 11 \\
\hline Orange & 2 & 2.5 & 2 & 3 & 9.5 \\
\hline Apple & 1 & 0 & 0 & 8 & 9 \\
\hline Nance & 0 & 0 & 8 & 0 & 8 \\
\hline Melon & 0.5 & 0 & 0 & 5 & 5.5 \\
\hline \multicolumn{6}{|l|}{ Vegetables } \\
\hline Tomato & 3 & 11 & 6.5 & 0 & 20.5 \\
\hline Carrot & 0 & 8.7 & 0.5 & 0 & 9.2 \\
\hline Zucchini & 0 & 6.2 & 0.5 & 0 & 6.7 \\
\hline Chayote fruit & 0 & 5.2 & 0.5 & 0 & 5.7 \\
\hline \multicolumn{6}{|l|}{ Legumes } \\
\hline Beans & 0 & 22.5 & 1.5 & 0 & 24 \\
\hline Lentils & 0 & 5 & 0.5 & 0 & 5.5 \\
\hline \multicolumn{6}{|l|}{$A D P$} \\
\hline Pork meat & 3 & 31 & 6 & 0 & 40 \\
\hline Eggs & 16 & 13 & 7 & 0 & 36 \\
\hline Chicken & 3 & 23.5 & 9 & 0 & 35.5 \\
\hline High-fat cheese & 16 & 0 & 11 & 0 & 27 \\
\hline Low-fat milk & 12.5 & 0 & 11 & 0 & 23.5 \\
\hline Pork ham & 7 & 0 & 6 & 0 & 13 \\
\hline Fish & 0 & 9 & 1.5 & 0 & 10.5 \\
\hline Beef & 0 & 6 & 2 & 0 & 8 \\
\hline Whole milk & 3 & 0 & 3 & 2 & 8 \\
\hline Low-fat cheese & 0 & 0 & 2 & 0 & 2 \\
\hline \multicolumn{6}{|l|}{ Fats and oils } \\
\hline Corn oil & 5.5 & 8 & 2 & 0 & 15.5 \\
\hline Sausages & 0 & 2 & 3 & 0 & 5 \\
\hline \multicolumn{6}{|l|}{ Bottled beverages } \\
\hline Sweated beverages & 8 & 15 & 2 & 0 & 25 \\
\hline \multicolumn{6}{|l|}{ NCP } \\
\hline Coffee & 21 & 0 & 9 & 0 & 30 \\
\hline Non-caloric sweeteners & 7 & 0 & 0 & 1 & 8 \\
\hline
\end{tabular}

Note: serving portions according to the Mexican Food Equivalence System and presented as frequency in descendent order. ADP = animal-derived products; $\mathrm{NCP}=$ non-caloric products. 
Table 3. Energy and macronutrients descriptive analysis among Mayan community women with type 2 diabetes.

\begin{tabular}{|c|c|}
\hline & $\begin{array}{c}\text { Participants } \\
n=57\end{array}$ \\
\hline Variables & Mean \pm SD/ Median (IQR) \\
\hline \multicolumn{2}{|l|}{ Total energy } \\
\hline kcal/day & $1664 \pm 515$ \\
\hline \multicolumn{2}{|l|}{ Protein } \\
\hline$\%$ of TEV & $16.5 \pm 3.3$ \\
\hline kcal of TEV & $240 \pm 79$ \\
\hline g/day & $60.0 \pm 19.7$ \\
\hline g/kg/day & $1.1 \pm 0.4$ \\
\hline \multicolumn{2}{|l|}{ Lipids } \\
\hline$\%$ of TEV & $22.8 \pm 9.2$ \\
\hline kcal of TEV & $346 \pm 196$ \\
\hline g/day & $38.4 \pm 21.7$ \\
\hline Cholesterol (mg) & $206.7 \pm 157.1$ \\
\hline \multicolumn{2}{|l|}{ Carbohydrates } \\
\hline$\%$ of VET & $60.5 \pm 9.1$ \\
\hline kcal of VET & $877 \pm 319$ \\
\hline g/day & $223.3 \pm 74.7$ \\
\hline Added sugars (g) & $8.7(30.0)$ \\
\hline Added sugars (kcal) & $30.0(120.0)$ \\
\hline Fiber (g) & $16.2 \pm 7.3$ \\
\hline
\end{tabular}

Note: results presented in mean \pm SD, except for Added sugars, which are expressed in Median (IQR [interquartile range]).

Abbreviations: $\mathrm{SD}=$ standard deviation; $\mathrm{TEV}=$ total energetic value. 
Table 4. Comparative analysis between Komchen's diet with the established ideal criterion, divided into energy and macronutrients.

\begin{tabular}{lccc}
\hline \multicolumn{1}{c}{$\begin{array}{c}\text { Participants } \\
n=57\end{array}$} & & \\
\multicolumn{1}{c}{ Variables } & Mean \pm SD & Ideal criteria & $p$ value \\
\hline Total energy (kcal) & $1664 \pm 515$ & $1273 \pm 110^{\mathrm{a}}$ & $\mathbf{0 . 0 0 0 1}$ \\
Carbohydrates (\% from TEV) & $60.5 \pm 9.1$ & $52.5 \pm 2.5^{\mathrm{b}}$ & $<\mathbf{0 0 0 1}$ \\
Protein (\% from TEV) & $16.5 \pm 3.3$ & $17.5 \pm 2.5^{\mathrm{b}}$ & $\mathbf{0 . 0 2 1 5}$ \\
Fat $(\%$ from TEV) & $22.8 \pm 9.2$ & $27.5 \pm 2.5^{\mathrm{b}}$ & $\mathbf{0 . 0 0 0 4}$ \\
Cholesterol (mg) & $203.3 \pm 157.5$ & $<200^{\mathrm{b}}$ & 0.4382 \\
Fiber (g) & $16.2 \pm 7.3$ & $23.2 \pm 7.3^{\mathrm{c}}$ & $<\mathbf{0 0 0 1}$ \\
\hline
\end{tabular}

Note: means comparison performed by a paired Student $t$-test. Mean comparison $v s$ pre-established population cut-off points performed by hypothesis test.

Abbreviations: $\mathrm{TEV}=$ total energy value.

a Ideal body weight x $25 \mathrm{kcal} / \mathrm{kg} /$ day, according to NOM-015-SSA2-2010.

b NOM NOM-015-SSA2-2010 recommended intake.

c14 gr of fiber per 1,000 kcal as ideal criterion, in agreement with NOM NOM-015-SSA2-2010.

\section{Discussion}

A major treatment for T2DM is nutritional surveillance, which must be adequate in quantity, quality, and nutrient distribution in order to promote weight and glycemic control. In this study, we aimed to describe eating patterns and biophysical conditions of previously diagnosed and currently under treatment individuals with T2DM from a semi-urban Mayan community of Yucatan. Our analytical procedure included a dietary characterization along with hypothesis t-test to compare the community's health condition with pre-established T2DM control cut-off points. We found that energy, carbohydrates, and fat intake, as well as $\mathrm{HbA1c}$, waist circumference, visceral fat level, and weight, significantly exceeded therapeutic recommendations. This is the first time that a dietary specific depiction is performed and reported in a Mexican Mayan community.

Dietary analysis showed that energy consumption exceeds recommended parameters in more than $300 \mathrm{kcal} /$ day, which surpasses approximately $25 \%$ of the suggested caloric intake for this particular population. Grain-based products constitute the largest food intake among this Mayan sample, which corresponds with what is reported nationally. Although tortilla consumption has partially declined during the last decades' nutritional transition, it remains the main grain-based product in Mexican culture [19]. High consumption of low-fat cookies among Komchen's population is notable. This product, which refined flour is its main component, is frequently consumed for breakfast and dinner without adding any other ingredient, except for coffee. Consequently, daily energy and carbohydrates consumption significantly exceed therapeutic nutritional recommendations, due to large refined grain-derived products, combined with the consumption of traditional tortillas. Insufficient vegetable and fruit intake also produced a daily fiber intake under Mexican recommendations [14] and also $6 \mathrm{~g}$ below the national average consumption in women [20], which contributes to T2DM progression and decontrol. However, added sugar consumption was lower than the national average for women ( $36 \mathrm{~g}$ vs $52 \mathrm{~g}$ ) [20], presumably associated with medical sugar intake prohibition as the only nutritional recommendation learned. In the same sense, protein and lipid consumption are underneath the therapeutic reference [14]. Specifically, Komchen's lipid intake is 
below the national average intake ( $38 \mathrm{~g}$ vs $59 \mathrm{~g}$ ), presumably due to large daily intake of cereals, although protein consumption remains similar to national average consumption [20].

Despite high-nutritional value food remaining as part of their diet, Mayan communities also excessively consume foods containing refined flour and bottled sugared beverages. These highenergy-density foods are vastly accessible in the community.

Regarding biophysical factors, sample's HbA1c mean average significantly surpasses ideal criterion for T2DM control, this result coincides with National Health Institutions' data, where Yucatan has been in the last place nationally in terms of diabetes control [21]. Furthermore, overweight and obesity surpasses by $20 \%$ the combined national prevalence for women $(73 \%)$, as well as the BMI mean among other Mayan communities $(30.0 \pm 4.7 \mathrm{~kg} / \mathrm{m} 2$ vs $28.8 \pm 4.6)[7,22]$. Our findings suggest that diet could be a related factor to this higher prevalence.

Nevertheless, one of the study's limitations is its cross-sectional design, since regional food could be influenced by festive and religious traditions during the year. Although, the community's diet usually remains constant, a longitudinal dietary survey could be a valid alternative methodology. On the other hand, sample size is representative since individuals with T2DM registered in Komchen community's public clinic reached a total of 200. However, this study provides evidence regarding inadequate eating habits among a suburban Mayan community previously diagnosed with T2DM. Despite the fact that some results partially coincide with what has already been reported in the Mexican population, this study adds value by providing a specific description of the nutrient distribution and current food consumption of indigenous Mayan women with T2DM.

Feeding habits reported in this community aggravates T2DM condition and could be the most relevant etiological factor. The aforementioned is fundamental for decision making regarding T2DM prevention and health promotion in this population.

Acknowledgments: We thank the Nutrition students from the 7th generation of the Marista University of Merida for data collection contribution.

Declarations of interest: The authors declare no conflict of interest.

Financial statement: This research did not receive any specific grants from funding agencies in the public sector, commercial, or not-for-profit sectors. 


\section{References}

1. J. Becerril, J. Castañeda, C. Solís, Pobreza, agrodiversidad y nutrición en el Yucatán rural, 2010, Av. En Investig. Agropecu. 18 (2014) 81-100.

2. C.A. Monteiro, G. Cannon, J.C. Moubarac, R.B. Levy, M.L.C. Louzada, P.C. Jaime, The un Decade of Nutrition, the NOVA food classification and the trouble with ultra-processing, Public Health Nutr. 21 (2018) 5-17. doi:10.1017/S1368980017000234.

3. Instituto Nacional de Estadística y Geografía, Lengua Indígena, (2010). https://www.inegi.org.mx/temas/lengua/ (accessed April 24, 2019).

4. M.G. Gutierrez Carbajal, M.Á. Magaña Magaña, Migración e influencia urbana en el consumo de alimentos en dos comunidades Mayas de Yucatán, Estud. Soc. Rev. Aliment. Contemp. Y Desarro. Reg. 27 (2017) 9-12. doi:10.24836/es.v27i50.429.

5. G.S.R. Alina Dioné Marín Cárdenas, L.L.M. Rodríguez, Prevalencia de obesidad y hábitos alimentarios desde el enfoque de género : el caso de Dzutóh , Yucatán, México, Estud. Soc. (2013). http://www.scielo.org.mx/pdf/estsoc/v22n44/v22n44a3.pdf.

6. A.G. De Fuentes, J. Morales, Dinámica regional de Yucatán 1980-2000, Investig. Geográficas. 42 (2000) 157-172. www.scielo.org.mx/pdf/igeo/n42/n42a10.pdf.

7. A. Loria, P. Arroyo, V. Fernandez, J. Pardio, H. Laviada, Prevalence of obesity and diabetes in the socioeconomic transition of rural Mayas of Yucatan from 1962 to 2000, Ethn. Heal. 0 (2018) 1-7. doi:10.1080/13557858.2018.1442560.

8. Ayuntamiento de Mérida, Diagnóstico Estadístico y Situacional del Municipio de Mérida, Yucatán, (2015). http://www.merida.gob.mx/yosirespeto/portal/umaip/contenido/poas/diagnostico.pdf.

9. D.D. Sampson, Interconnections Of Agrobiodiversity And Food Security In Rural Yucatan, Mexico, University of California Santa Cruz, 2015.

https://cloudfront.escholarship.org/dist/prd/content/qt1j46k3cc/qt1j46k3cc.pdf?t=nrlboy.

10. Secretaría de Desarrollo Social, Catálogo de localidades, (2013).

http://www.microrregiones.gob.mx/catloc/LocdeMun.aspx?ent=31\&mun=050 (accessed April 24, 2019).

11. Diario Oficial de la Federación, Norma Oficial Mexicana NOM-008-SSA3-2017, Para el tratamiento integral del sobrepeso y la obesidad, (2017).

http://www.dof.gob.mx/nota_detalle.php?codigo=5469855\&fecha=25/01/2017.\%09 (accessed October 25, 2018).

12. World Health Organization, Waist Circumference and Waist-Hip Ratio Report of a WHO Expert Consultation, (2008) 1-39.

https://apps.who.int/iris/bitstream/handle/10665/44583/9789241501491_eng.pdf;jsessionid=9C2152D70B35 323FE81FD31BB98DB0DA?sequence=1. (accessed December 11, 2019).

13. E. Barbosa, A. Coca, P. Lopez-Jaramillo, A.J. Ramirez, R.A. Sanchez, A. Zanchetti, Guidelines on the management of arterial hypertension and related comorbidities in Latin America, J. Hypertens. 35 (2017) 1529-1545. doi:10.1097/HJH.0000000000001418.

14. Diario Oficial de la Federación, Norma Oficial Mexicana NOM-015-SSA2-2010, Para la prevención, tratamiento y control de la diabetes mellitus, (2010).

http://dof.gob.mx/nota_detalle.php?codigo=5168074\&fecha=23/11/2010. (accessed November 23, 2018).

15. A.B. Perez-Lizaur, B. Palacios-Gonzalez, A.L. Castro-Becerra, I. Flores-Galicia, Sistema Mexicano de Alimentos Equivalentes, 4th ed., Ogali, Mexico City, 2014.

16. F.B.H. Sylvia H. Ley, Osama Hamdy, V. Mohan, Prevention and Management of Type 2 Diabetes: Dietary Components and Nutritional Strategies, Lancet. 383 (2014) 1999-2007. doi:10.1016/S0140-6736(14)60613-9.

17. Diario Oficial de la Federación, NORMA Oficial Mexicana NOM-012-SSA3-2012, Que establece los criterios para la ejecución de proyectos de investigación para la salud en seres humanos., (2012). http://dof.gob.mx/nota_detalle.php?codigo=5284148\&fecha=04/01/2013 (accessed January 22, 2019).

18. United States Department of Agriculture, National Nutrient Database for Standard Reference Legacy Release, (2018).

https://ndb.nal.usda.gov/ndb/foods/show/18955?fgcd=\&manu=\&format=\&count=\&max=25\&offset=\&sort

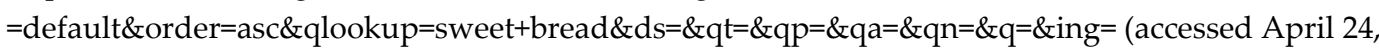
2019). 
19. T.C. Aburto, L.S. Pedraza, T.G. Sánchez-Pimienta, C. Batis, J.A. Rivera, Discretionary Foods Have a High Contribution and Fruit, Vegetables, and Legumes Have a Low Contribution to the Total Energy Intake of the Mexican Population, J. Nutr. 146 (2016) 1881S-1887S. doi:10.3945/jn.115.219121.

20. N. López-Olmedo, A.L. Carriquiry, S. Rodríguez-Ramírez, I. Ramírez-Silva, J. Espinosa-Montero, L. Hernández-Barrera, F. Campirano, B. Martínez-Tapia, J.A. Rivera, Usual Intake of Added Sugars and Saturated Fats Is High while Dietary Fiber Is Low in the Mexican Population, J. Nutr. 146 (2016) 1856S1865S. doi:10.3945/jn.115.218214.

21. Observatorio Mexicano de Enfermedades No transmisibles, Tablero de Control de Enfermedades Crónicas, (2019). http://oment.uanl.mx/tablero-de-control-de-enfermedades/ (accessed May 13, 2019). C.-N.L. Gutiérrez JP, Rivera-Dommarco J, Shamah-Levy T, Villalpando-Hernández S, Franco A, H.-Á.M. Romero-Martínez M, Encuesta Nacional de Nutricion y Salud, (2012) 200. 